\title{
PENGARUH EKSTRAK BUAH TOMAT (Lycopersicum esculentum L.) TERHADAP KADAR HORMON TESTOSTERON TIKUS PUTIH (Rattus novergicus L.) YANG DIBERI PAKAN TINGGI KOLESTEROL
}

\author{
Firstia Ritri Wulandari ${ }^{1}$, Teuku Mamfalutfi ${ }^{2}$, Dasrul ${ }^{3}$, Rajuddin ${ }^{4}$ \\ ${ }^{1}$ Mahasiswa Fakultas Kedokteran Universitas Syiah Kuala \\ ${ }^{2}$ Staf Pengajar Fakultas Kedokteran Universitas Syiah Kuala \\ ${ }^{3}$ Staf Pengajar Fakultas Kedokteran Hewan Universitas Syiah Kuala; \\ ${ }^{4}$ Bagian Obstetri dan Ginekologi Fakultas Kedokteran Universitas Syiah Kuala \\ Corresponding author : rajud88@gmail.com
}

\begin{abstract}
Abstrak
Penelitian ini bertujuan untuk mengetahui pengaruh pemberian ekstrak buah tomat (Lycopersicum esculentum L.) terhadap kadarhormontestosterontikus putih (Rattus novergicus L.) yang diberi pakan tinggi kolesterol. Penelitian ini merupakan penelitian eksperimental laboratorik jenis Posttest Only Control Group Design, dengan menggunakan 30 ekor tikus putih jantan yang dibagi secara acak dalam lima kelompok perlakuan masing-masing,1) kelompok kontrol negatif(KN)tikus diberi pakan standar, 2) kelompok kontrol positif (KP)tikus diberi pakan tinggi kolesterol, 3) kelompok tikus yang diberi pakan tinggi kolesterol dan eksrak tomat $25 \mathrm{mg} / \mathrm{kgBB} /$ hari (D1), 4) kelompok tikus yang diberi pakan tinggi kolesterol dan ekstrak tomat dosis $50 \mathrm{mg} / \mathrm{kgBB} / \mathrm{hari}$ (D2) dan 5) kelompok tikus yang diberi pakan tinggi kolesterol dan, ekstrak tomat dosis $100 \mathrm{mg} / \mathrm{kgBB} /$ hari (D3) selama 60 hari. Koleksi sampel darah dilakukan melalui vena orbitalis menggunakan mikropipet. Pengukuran kadar testosteron darah tikus dilakukan dengan menggunakan metode Enzyme-linked immunosorbent assay (ELISA). Data dianalisis dengan uji statistik non parametric menggunakan uji Kruskall Wallis dan di lanjutkan dengan uji Mann-Whitney.Hasil penelitian menunjukkan pemberian ekstrak tomat dapat meningkatkan kadar hormon testosteron darah tikus putih yang diberi pakan tinggi kolesterol seiring dengan tingkat dosis yang diberikan. Pemberian ekstrak tomat dosis $100 \mathrm{mg} / \mathrm{kgBB} / \mathrm{hari}$ (D3)berbeda secara nyata $(p<0,05)$ dibandingkan dengan kontrol positif $(\mathrm{KP})$., ekstrak tomat dosis 25 $\mathrm{mg} / \mathrm{kgBB} /$ hari (D1)dan ekstrak tomat dosis $50 \mathrm{mg} / \mathrm{kgBB} /$ hari (D2)., namun tidak berbeda dengan kontrol negatif $(\mathrm{KN})$. Pemberian ekstrak tomat dapat meningkatkan kadar hormon testosteron serum darah tikus putih yang diberi pakan tinggi kolesterol.
\end{abstract}

Kata Kunci: kolesterol; testosterone; tomat; tikus putih 


\title{
EFFECT OF EXTRACT OF TOMATO (Lycopersicum esculentum L.) TOWARD TESTOSTERONE LEVELS OF WHITE MICE (Rattus novergicus L.) FED HIGH CHOLESTEROL
}

\begin{abstract}
The purpose of this study was to determine the effect of the extract of tomato (Lycopersicum esculentum) against the testosterone levels of white mice (Rattus novergicus L.) fed high cholesterol. This research was a experimental laboratory research using 30 male mice randomly divided into five treatment groups. 1) negative control group (KN) mice fed by a standard feeding, 2) positive control group (KP) mice were fed by a high-cholesterol, 3) groups of mice fed by a highcholesterol and extracts tomatoes $25 \mathrm{mg} / \mathrm{kg} /$ day (D1), 4 ) mice were fed by a highcholesterol feeding and tomato extract dose of $50 \mathrm{mg} / \mathrm{kg} /$ day (D2) and 5) the group of mice fed high cholesterol, tomato extract dose $100 \mathrm{mg}$ - kg- day (D3) for 60 days. Blood sample was collectedthrough the orbital vein using a micropipette. The measurement of mice blood testosterone levels performed using enzymelinked immunosorbent assay (ELISA). Data were analyzed using non-parametric statistical tests using Kruskal Wallis test and proceed with the Mann-Whitney test. The results showed the tomato extract could increase the blood levels of testosterone hormones in white mices fed by a high cholesterol level in line with the dose administered. Which dose 100 tomato extract $\mathrm{mg} / \mathrm{kg} /$ day (D3) differed significantly $(\mathrm{p}<0.05)$ compared to positive control $(\mathrm{KP})$, group, $25 \mathrm{mg} / \mathrm{kg} /$ day, 50 $\mathrm{mg} / \mathrm{kg} /$ day(D2), but there was no differentcet from the negative control $(\mathrm{KN})$. It was concluded that the tomato extract may increase blood serum levels of testosterone in white mice fed with a high cholesterol.
\end{abstract}

Keywords: cholesterol; teststosterone; tomato; white mice 


\section{Pendahuluan}

Kemajuan teknologi informasi dan ekonomi menyebabkan terjadinya perubahan pola makan. Mengkonsumsi makanan berkolesterol tinggi berisiko terhadap peningkatan kadar kolesterol yang melebihi batas normal dalam darah. Penyakit ini dikenal dengan istilah hiperkolesterolemia.(1,2)dindikasikan

denganpeningkatan kadar kolesterol total, trigliserida danLow Density Lipoprotein (LDL) serta penurunan kadar High Density Lipoprotein (HDL).(2,3)

Banyak penelitian menunjukkan, terjadi peningkatan produksi radikal bebas dan ketidaksesuaian perkembangan lipid peroksida pada tingkat jaringan pada keadaan hiperkolesteterolemia, sehingga dapatmenyebabkan terjadinya gangguan fungsional tubuh secara umum.(4)Salah satu gangguan fungsional tubuh yang ditimbulkan akibat hiperkolesterolemiayaitu terjadinya gangguan fungsi reproduksi pria, berupamenurunnya libido (kegairahan/doronganseksual), gangguan ejakulasi, disfungsi ereksi dan penurunan produksi sperma yang selanjutnya dapat menyebabkan penurunan dari kualitas spermatozoa. ${ }^{(5,6)}$ Hiperkolesterolemia

dilaporkan juga dapat menyebabkan gangguan fungsi jalur hipofise-pituitarigonad, regulasi hormon testosteron yang disertai gangguan spermatogenesis, perubahan morfologi spermatozoa, degenerasi sel gonad dan penurunan kualitas spermatozoa. $(5,7,8,9)$ Hasil penelitian yang dilakukan terhadap tikus oleh Feng et al., ditemukan bahwa kadar testosteron plasma tikus hiperkolesterolemia menurun secara signifikan dibandingkan dengan tikus normal.(9)Penurunan kadar testosteron ini sebagai akibat terjadinya degenerasi sel Leydig, dan penurunan sekresi Luitunizing Hormone (LH) dari hipofisa anterior. ${ }^{(10,11)}$

Testosteron merupakan hormon yang sangat mendasar pada pria yang dihasilkan oleh sel Leydig.(6)Testosteron sangat dibutuhkan dalam proses spermatogenesis dari mulai pembelahan hingga pelepasan sel spermatozoa dari sel Sertoli menuju duktus epididimis.(8) Selain bertanggung jawab dalam spermatogenesis, testosteron juga bertanggung jawab dalam mengatur perilaku kejantanan, memicu kegairahan seksual, membantu terjadinya dan pemeliharaan ereksi pada penis.(5,11)Telah terbukti bahwa ada korelasi yang erat antara kadar testosteron dalam darah dengan penurunan kegairahan seksual, disfungsi ereksi atau kesulitan ereksi dan penurunan produksi spermatozoa.(11,12)Beberapa peneliti membuktikan faktor utama pemicu terjadinya penurunan kadar hormon testosteron, gangguan disfungsi ereksi danpenurunan kualitas spermatozoa pada penderita hiperkolesterolemia adalah akibat adanya peningkatan senyawa oksigen reaktif atau reactive oxygen spesies (ROS) yang selanjutnya menyebabkan stres oksidatif pada organ reproduksi dan sperma. ${ }^{(1,9,12)}$ Kondisi ini terjadi karena kemampuan pertahanan tubuh meredam reaktivitas ROS melalui sistem antioksidan tubuh berkurang, sehingga dibutuhkan suplai antioksidan dari luar tubuh.(7)

Sejalan dengan Program Organisasi Kesehatan Dunia (World Health Organization/WHO) yang mencetuskan suatu slogan "kembali ke alam" dalam upaya mencari, meneliti dan menggunakan bahan alami nabati untuk mengatasi berbagai macam penyakit degenerative, salah satunyainfertilitas para peneliti dari berbagai bidang ilmu kini mulai mencoba menggunakan bahan kimia alami berupa senyawa fitokimia yang banyak terdapat dalam buah-buahan dan dikenal sebagai infertility prevention.

Penggunakan senyawa fitokimia untuk pencegahan infertilitas merupakan salah satu upaya menggunakan bahan kimia alam yang diharapkan dapat mencegah tahap awal infertilitas, sebelum terjadi secara 
permanen. Kriteria pemilihan senyawa kimia yang digunakan sebagai infertility prevention sangat berbeda dengan senyawa yang digunakan sebagai terapi infertilitas.Senyawa terapi infertilitas sering digunakan untuk meningkatkan libido dan produksi sperma secara cepat, bahkan juga menghasilkan pengaruh yang kurang baik pada penderita.Sebaliknya senyawa infertility prevention yang digunakan umumnya bersifat tidak beracun dan relatif bebas dari pengaruh buruk lainnya. Senyawa kimia pencegah infertilitas pada berbagai tanaman diantaranya adalah senyawa-senyawa antioksidan seperti senyawa karatinoid, flavonoid, vitamin C dan vitamin $\mathrm{E}$ yang banyak ditemukan pada sayuran dan buah-buahan.(13)

Tomat (Lycopersicum esculentum) merupakan salah satu sayuran kaya akan senyawa antioksidan seperti vitamin $\mathrm{E}$, vitamin C, likopen, karatinoid, dan flavonoid yang penting untuk kesehatan.(13)Buah tomat selain sebagai sayuran juga banyak dimanfaatkan masyarakat untuk mengobati beberapa penyakit antara lain sebagai antiradang, anti kanker terutama kanker prostat,(14)hipertensi dan penyakit jantung koroner,(15) menurunkan kadar kolesterol dan LDL yang tinggi ${ }^{(16,17)}$ dan meningkatkan kualitas spermatozoa. ${ }^{(18)}$ Hasil penelitian menunjukan bahwa pemberian ekstrak buah tomat dosis $40-80 \mathrm{mg} / \mathrm{kgBB} /$ hari, selama 60 haripadatikus putih yang diberi pakan tinggi kolesterol dapat meningkatkan spermatogensis dan kualitas spermatozoa.(19)Namun kajian tentang pengaruh pemberian ekstrak buah tomatterhadap peningkatan kadar testosteron darah tikus putih yang diberi pakan tinggi kolesterol belum pernah dilaporkan. Berdasarkan hal tersebut, maka peneliti inginmelakukan suatu penelitian yang mengkaji tentang perbandingan efektivitas pemberian ekstrak tomat terhadap kadar hormon testosteron plasma darah tikus (Rattus norvegicus) strain Wistar yang diberi pakan tinggi kolesterol.

\section{Metode Penelitian}

Penelitian ini merupakan penelitian eksperimental laboratorik jenis Postest Only Control Group Design, dengan menggunakan Rancangan Acak Lengkap (RAL) pola satu arah dengan lima kelompok perlakuan. Kelompok 1 sebagai kontrol negatif $(\mathrm{KN})$ yaitu tikus yang diberi pakan normal. Kelompok 2 sebagai kontrol positif (KP) yaitu tikus yang diberi pakan tinggi kolesterol.Kelompok 3 sebagai dosis 1 (D1) yaitu tikus yang diberi pakan tinggi kolesterol dan ekstrak tomat $25 \mathrm{mg} / \mathrm{kgBB} /$ hari. Kelompok 4 sebagai dosis 2 (D2) yaitu tikus yang diberi pakan tinggi kolesterol dan ekstraktomat 50 $\mathrm{mg} / \mathrm{kgBB} /$ hari.Kelompok 5 sebagai dosis 3 (D3) yaitu tikus yang diberi pakan tinggi kolesterol dan ekstrak tomat 100 $\mathrm{mg} / \mathrm{kgBB} /$ hari.Pemberian ekstak tomat dilakukan selama 60 hari.

Adaptasi hewan uji hingga akhir perlakuan dilakukan di Laboratorium Hewan Coba Fakultas Kedokteran Hewan Universitas Syiah Kuala (Unsyiah).Selanjutnya analisis hormon testosteron serum tikus yang telah diberikan perlakuan dilakukan di Laboratorium Riset Fakultas Kedokteran Hewan Unsyiah.Sementara itu pembuatan ekstrak tomat dilakukan di Laboratorium Kimia FMIPA Unsyiah.Waktu penelitian mulai dari bulan Juni hingga Desember 2015.

Hewan uji tikus putih (Rattus norvegicus) strain Wistar diperoleh dari Laboratorium Hewan Coba Fakultas Kedokteran Universitas Sumatera Utara. Tikus putih yang digunakan berjenis kelamin jantan, berumur 3-4 bulan dengan berat badan 150-200 gram, tidak memperlihatkan abnormalitas anatomis makro dan belum pernah mendapatkan perlakuan apapun sebelumnya. Pada tahap 
adaptasi semua tikus putih diberi ransum standar T79-4.

Pakan tinggi kolesterol yang diberikan pada saat perlakuan mengandung kolesterol $2 \%$, terbuat dari bahan-bahan: 3 gram telor itik (kuning telur), 3 gram mentega, 2.5 gram keju, dan 1.5 gram minyak kelapa. Bahan-bahan tersebut dicampurkan menjadi satu, lalu diberikan kepada hewan coba dengan cara oral melalui sonde lambung sebanyak 1cc/ekor. $(20,21)$

Sebanyak 1500 gram tomat (Lycopersicum esculentum) jenis apel segar diperoleh dari perkebunan masyarakat sekitar Banda Aceh. Tomat dipilih dalam kondisi yang segar, memiliki tingkat kematangan yang sama. Tomat dicuci dengan air sampai bersih, dipotong kecilkecil lalu diblender. Tomat dimaserasi dengan menggunakan pelarut etanol $70 \%$ selama 3×24 jam sampai didapat maserat yang jernih, kemudian dievaporasi dengan menggunakan rotary evaporator vacum sampai diperoleh ekstrak pekat dan ditimbang beratnya. ${ }^{(22,23)}$

Masing-masing tikus ditimbang pada akhir masa adaptasi untuk mengetahui beratnya guna memenuhi kriteria inklusi yang telah ditetapkan, kemudian semua tikus diambil darahnya. Sebelum pengambilan darah tikus dipuasakan terlebih dahulu selama 10-12 jam, dan hasilnya digunakan sebagai patokan awal (baseline) kadar kolesterol tikus sebelum perlakuan. Selanjutnya sebanyak 30 ekor tikus dibagi secara acak menjadi lima kelompok perlakuan sebagaimana telah dijelaskan di atas dan masing-masing perlakuan terdiri dari enam ulangan.

Pemberian ekstrak tomat sesuai perlakuan dilakukan 15 menit sebelum pemberian pakan tinggi kolesterol. Pemberian ektrak dengan volume 0,5 $\mathrm{ml}$ /ekor dilakukan secara oral, menggunakan sonde lambung. Pemberian ekstak tomat dilakukan selama 60
hari.Semua tikus perlakuan diberi air minum secara ad libitumselama penelitian.

Darah tikus diambil menggunakan pipet kapiler melalui vena orbitalis sebanyak 1cc, setelah 60 hari perlakuan.Darah tersebut selanjutnya dimasukkan ke dalam tabung reaksi steril dengan cara dialirkan secara perlahan melalui dinding tabung. Selanjutnya tabung reaksi tersebut diletakkan dalam termos berisi es pada posisi miring selama 5-6 jam atau sampai terlihat pemisahan antara serum dengan benda darah. Serum diambil dengan menggunakan pipet steril dan di masukkan ke dalam ependorf, lalu di simpan dalam refrigerator dengan suhu $-20^{\circ} \mathrm{C}$ hingga dilakukan pemeriksaan terhadap kadar testosteron.

Kadar hormon testosteron yang terdapat dalam serum darah, dianaliis dengan metode Enzyme-linked immunesorbent assay (ELISA), menggunakan kit total testosteron (COAT-A-COUNT Total Testosterone, EIA 1559, DRG, Germany).

Analisis data dilakukan terhadap kadar hormon testosteron secara statistik, sebelumnya dilakukan uji normalitas dengan menggunakan uji KolmogorovSmirnov dan homegenitas dengan menggunakan uji Levene.(24)Hasil uji normalitas menunjukkan bahwa data tidak terdistribusi normal. Oleh karena itu data dianalisis dengan uji statistik non parametrik menggunakan uji Kruskall Wallis dan di lanjutkan dengan uji MannWhitney.Analisis data di lakukan dengan bantuan Software SPSS versi 20.

\section{Hasil Penelitian}

Hasil analisis kadar hormon testosteron serum darah tikus putih stran Wistar yang diberi pakan tinggi kolesterol dan perlakuan berbagai dosis ekstrak buah tomat dapat dilihat pada tabel 4.1.

Secara histogram rata-rata kadar testosteron serum darah kelompok kontrol 
normal $(\mathrm{KN})$, yang diberi pakan tinggi kolesterol (KP), yang diberi pakan tinggi kolesterol dan ekstrak buah tomat dosis 25 $\mathrm{mg} / \mathrm{kgBB} / \mathrm{hari}$ (D1), $50 \mathrm{mg} / \mathrm{kgBB} / \mathrm{hari}$ (D2) dan $100 \mathrm{mg} / \mathrm{kgBB} /$ hari (D3) dapat dilihat pada gambar 1 .

Tabel 1 Data kadar hormon testosteron serum darah tikus putih strain Wistar pada berbagai kelompok perlakuan ekstrak tomat $(\mathrm{ng} / \mathrm{ml})$

\begin{tabular}{cccccc}
\hline \multirow{2}{*}{ Ulangan } & \multicolumn{5}{c}{ Kelompok Perlakuan } \\
\cline { 2 - 6 } & KN & KP & D1 & D2 & D3 \\
\hline Tikus I & 1,332 & 0,512 & 0,606 & 0,734 & 1,024 \\
Tikus II & 2,338 & 0,328 & 0,368 & 0,652 & 1,823 \\
Tikus III & 1,422 & 0,432 & 0,618 & 0,586 & 1,230 \\
Tikus IV & 1,070 & 0,397 & 0,452 & 0,875 & 1,512 \\
Tikus V & 2,314 & 0,413 & 0,583 & 0,703 & 1,690 \\
Tikus VI & 2,024 & 0,476 & 0,666 & 0,633 & 1,334 \\
\hline Rata-rata & 1,83 & 0,41 & 0,54 & 0,69 & 1,52 \\
SD & 0,56 & 0,05 & 0,12 & 0,11 & 0,24 \\
\hline
\end{tabular}

Keterangan:

$\mathrm{KN}=$ Kelompok tikus putih yang diberi pakan normal

$\mathrm{KP}=$ Kelompok tikus putih yang diberi pakan tinggi kolesterol selama 60 hari

D1 = Kelompok tikus putih yang diberi pakan tinggi kolesteroldan ekstrak tomat $25 \mathrm{mg} / \mathrm{KgBB} /$ hari selama 60 hari

D2 $=$ Kelompok tikus putih yang diberi pakan tinggi kolesteroldan ekstrak tomat $50 \mathrm{mg} / \mathrm{KgBB} /$ hari selama 60 hari

D3 = Kelompok tikus putih yang diberi pakan tinggi kolesteroldan ekstrak tomat $100 \mathrm{mg} / \mathrm{KgBB} /$ hari selama 60 hari

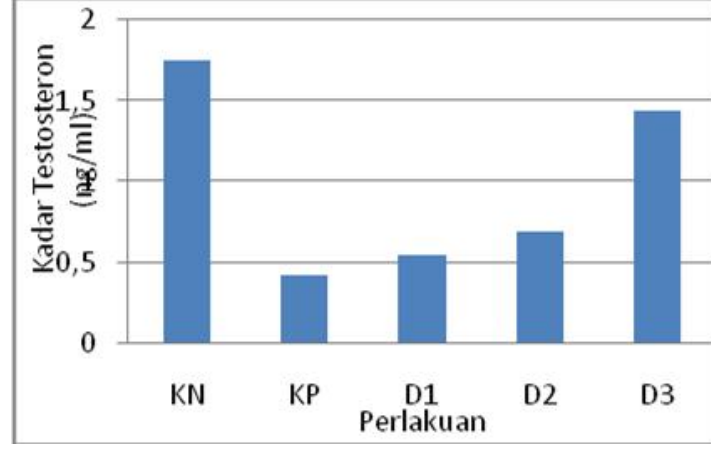

Gambar 1. Histogram kadar hormon testosteron serum darah tikus putih strain Wistar kelompok KN, KP, D1, D2 dan D3

Berdasarkan tabel 1 dan gambar 1 diatas terlihat bahwa distribusi data kadar hormon testosteron serum darah tikus strain Wistar berkisar antara 0,328 sampai 2,338 $\mathrm{ng} / \mathrm{mL}$. Nilai rata-rata kadar hormon testosteron serum pada perlakuan kontrol negatif $(\mathrm{KN})$ adalah $1,750 \mathrm{ng} / \mathrm{mL}$, mengalami penurunan menjadi 0,426 $\mathrm{ng} / \mathrm{mL}$ pada kelompok kontrol positif (KP), kemudian meningkat kembali seiring dengan peningkatan dosis 25 $\mathrm{mg} / \mathrm{kgBB} / \mathrm{hari}, 50 \mathrm{mg} / \mathrm{kgBB} /$ hari dan 100 $\mathrm{mg} / \mathrm{kgBB} /$ hari secara berturut-turut adalah menjadi $0,549 \mathrm{ng} / \mathrm{ml}, 0,697 \mathrm{ng} / \mathrm{mL}$, dan $1,463 \mathrm{ng} / \mathrm{mL}$.

Hasil uji normalitas dengan menggunakan uji Kolmogorov Smirnov didapatkan bahwa data terdistribusi secara tidak normal dengan nilai $p$ untuk 30 unit sampel (lima perlakuan dan enam ulangan) tidak berdistribusi normal dengan nilai $p$ adalah <0.001 (Tabel 2). Menurut kaidah statistik, jika data terdistribusi tidak normal maka analiasis data tidak boleh dilakukan secara parametrik, namun harus dilakukan secara non parametrik.Oleh karena itu, analisis data penelitian ini dilakukan dengan analisis non parametrik menggunakan uji Kruskal-Wallis.Uji KruskalWallis berfungsi untuk melihat ada atau tidaknya pengaruh perlakuan terhadap nilai konsentrasi hormon testosteron di dalam darah tikus putih yang diujikan. 
Tabel 2 Hasil uji Kolmogorov Smirnov terhadap sebaran data konsentrasi Hormon Testosteron

\begin{tabular}{ccccccc}
\hline & \multicolumn{3}{c}{$\begin{array}{c}\text { Kolmogorov- } \\
\text { Smirnova }\end{array}$} & \multicolumn{3}{c}{ Shapiro-Wilk } \\
\cline { 2 - 7 } & Stat. & df & Sig. & Stat. & df & Sig. \\
\hline Testosteron & .222 & 30 & .001 & .864 & 30 & .001 \\
\hline
\end{tabular}

a. Lilliefors Significance Correction

Keterangan :

Nilai $p$ dihitung menggunakan uji kolmogorov smirnov * $p<0.05$ (data terdistribusi tidak normal)

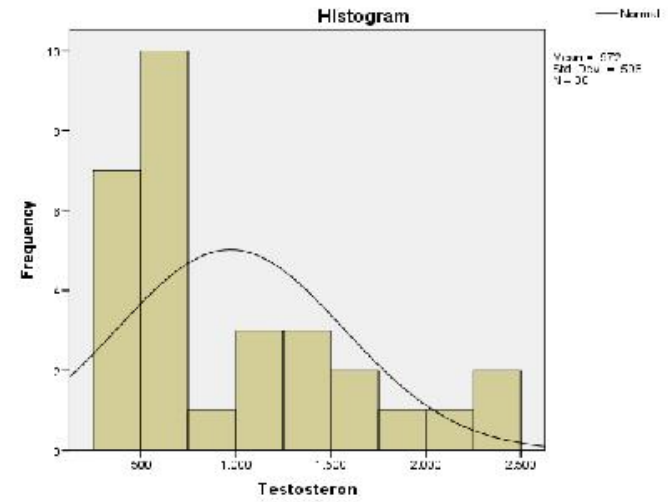

Gambar 2 Histogram uji normalitas hormon testosteron

Hasil uji Kruskal-Wallis sebagaimana terdapat pada Tabel 4.2, menunjukkan bahwa terdapat pengaruh perlakuan terhadap kadar hormon testosteron darah tikus putih (Chi-square 24,942; Sig. <0,05).

Tabel 3 Hasil uji Kruskal-Wallis Hormon Testosteron

\begin{tabular}{lc}
\hline & Testosteron \\
\hline Chi-Square & 24.942 \\
Df & 4 \\
Asymp. Sig. & .000 \\
\hline
\end{tabular}

a. Kruskal Wallis Test

b. Grouping Variable: Perlakuan

Keterangan :

Nilai $p$ dihitung menggunakan uji Kruskal-Wallis $p$ value $<0.05$ (didapatkan perbedaan)
Untuk mengetahui perlakuan mana saja yang berpengaruh dan mana yang tidak berpengaruh maka dilakukan uji lanjut dengan uji Mann-Whitney.Hasil uji lanjut Mann-Whitney menunjukkan bahwa perlakuan kontrol negatif $(\mathrm{KN})$ berbeda nyata dibandingkan dengan kontrol positif $(\mathrm{KP})$, dosis $25 \mathrm{mg} / \mathrm{kgBB} / \mathrm{hari}(\mathrm{D} 1)$ dan dosis $50 \mathrm{mg} / \mathrm{kgBB} / \mathrm{hari}$ (D2), namun tidak berbeda dengan dosis $100 \mathrm{mg} / \mathrm{kgBB} /$ hari (D3). Perlakuan KP berbeda nyata dibandingkan dengan D2 dan D3, namun tidak berbeda dengan D1, selanjutnya semua perlakuan D1, D2 dan D3 berbeda nyata diantaranya (Tabel 3).

Tabel 3 Hasil uji Mann-Whitney Hormon Testosteron

\begin{tabular}{cccc}
\hline Perlakuan & $\begin{array}{c}\text { Mann- } \\
\text { Whitney U }\end{array}$ & Sig. & Z \\
\hline KN - KP & 0,000 & $0,004^{*}$ & $-2,882$ \\
KN - D1 & 0,000 & $0,004^{*}$ & $-2,882$ \\
KN - D2 & 0,000 & $0,004^{*}$ & $-2,882$ \\
KN - D3 & 12,000 & $0,337^{n s}$ & $-0,961$ \\
KP - D1 & 7,000 & $0,075^{\text {ns }}$ & $-1,701$ \\
KP - D2 & 0,000 & $0,004^{*}$ & $-2,882$ \\
KP - D3 & 0,000 & $0,004^{*}$ & $-2,882$ \\
D1- D2 & 5,000 & $0,037^{*}$ & $-2,082$ \\
D1 - D3 & 0,000 & $0,004^{*}$ & $-2,882$ \\
D2 - D3 & 0,000 & $0,004^{*}$ & $-2,882$ \\
\hline
\end{tabular}

Keterangan :ns) tidak berbeda nyata; *) berbeda nyata pada taraf $Z=95 \%$

Uji Mann-Whitney menunjukan ada perbedaan yang nyata $(\mathrm{p}<0,05)$ antara kelompok perlakuan $\mathrm{KP}$ dengan $\mathrm{KN}$, D2 dan D3, namun tidak terdapat perbedaan yang nyata $(\mathrm{p}>0,05)$ dengan kelompok D1. Kadar hormon testosteron serum pada kelompok D1 berbeda secara nyata $(\mathrm{p}<0,05)$ dengan D2, D3 dan KN. Kadar hormon testosteron serum pada kelompok D2 berbeda secara nyata $(\mathrm{p}<0,05)$ dengan D3 dan KN. Sedangkan kadar hormon testosteron serum pada kelompok D3 tidak berbeda secara nyata $(p>0,05)$ dibandingkan 
dengan KN. Hasil ini mengindikasikan bahwa pemberian pakan tinggi kolesterol dan ekstrak buah tomat pada tikus putih dapat mempengaruhi kadar hormon testosteron dalam serum darah.

\section{Pembahasan}

Hormon testosteron merupakan suatu hormon steroid androgen yang penting dalam kehidupan seksual dan reproduksi baik wanita maupun pria. Selain fungsinya yang berpengaruh besar terhadap kehidupan seksual, testosteron juga memiliki efek biologik yang penting diantaranya pada metabolisme, integritas tulang, otot, sistem kardiovaskular dan otak berkurangnya hormon testosteron berpengaruh terhadap penurunan sensitivitas insulin, kelemahan otot, gangguan metabolisme karbohidrat, gangguan fungsi kognitif, berkurangnya dorongan motivasi, lelah dan letargi, peningkatan lemak tubuh, serta penurunan dorongan dan kemampuan seksual.(25)

Hormon testosteron pada pria diproduksi oleh sel Leydig di dalam testis sebanyak $95 \%$ sedangkan sisanya diproduksi oleh cortex adrenal.Sebanyak 98\% testosteron terikat pada protein plasma, yang meliputi albumin dan steroid hormonbinding globulin (SHBG).Sisanya sebesar 2\% merupakan testosteron bebas karena beredar dalam keadaan tidak terikat pada protein apapun yang mengalir dalam darah. Persentase testosteron yang terikat pada SHBG bervariasi antar individu, tetapi pada umumnya sekitar $40-80 \%$ dari testosteron yang beredar.(25) Banyak bukti menunjukan bahwa tinggi rendahnya kadar testosteron dalam darah dipengaruhi oleh banyak faktor diantaranya faktor eksternal seperti alkohol, obat-obatan, trauma testis, infeksi dan merokok sementara faktor internal dipengaruhi oleh penuaan, obesitas, kurang tidur, penyakit kronis dan hiperkolesterolemia. Hubungan antara tingginya kadar kolesterol dalam darah dengan konsentrasi testosteron berpengaruh secara berbanding terbalik. Hal ini terjadi akibat munculnya enzim inhibisi pada testis yang menurunkan konversi kolesterol menjadi testosteron.Kadar testosteron kirakira $25 \%$ pada keadaan hiperkolesterolemia. ${ }^{(12)}$

Hasil pengukuran kadar hormon testosteron serum pada penelitian ini memperlihatkan adanya perbedaan yang nyata diantara perlakuan. Rata-rata kadar hormon testosteron serum yang diperoleh pada kelompok tikus putih strain Wistar normal atau kontrol negatif $(\mathrm{KN})$ adalah yaitu $1,83 \pm 0,56 \mathrm{ng} / \mathrm{mL}$, mengalami penurunan menjadi $0,41 \pm 0,05 \mathrm{ng} / \mathrm{ml}$ pada kelompok tikus yang pakan tinggi kolesterol (KP). Kemudian meningkat pada kelompok tikus yang diberi pakan tinggi kolesterol dan ekstrak buah tomat dosis $25 \mathrm{mg} / \mathrm{kgBB}$, $50 \mathrm{mg} / \mathrm{kgBB}$ dan $100 \mathrm{mg} / \mathrm{kgBB}$. Hasil analisis statistik menunjukan perbedaan yang nyata diantar kelompok perlakuan. Kadar hormon testosteron serum pada kelompok KP lebih rendah secara nyata $(\mathrm{p}<0,05)$ dibandingkan dengan kelompok $\mathrm{KN}$, D2 dan D3, namun tidak berbeda secara nyata $(p>0,05)$ dibandingkan dengan D1. Kadar hormon testosteron serum pada kelompok D1 lebih rendah secara nyata $(\mathrm{p}<0,05)$ dengan D2, D3 dan KN. Kadar hormon testosteron serum pada kelompok D2 lebih rendah secara nyata $(p<0,05)$ dibandingkan dengan D3 dan $\mathrm{KN}$. Sedangkan kadar testosteron serum pada kelompok D3 tidak berbeda secara nyata $(p>0,05)$ dibandingkan KN. Hal ini membuktikan bahwa pemberian pakan tinggi kolesterol pada tikus putih dapat menurunkan kadar hormon testosteron serum tikus putih strain Wistar, sedangkan pemberian ekstrak buah tomat dosis 50-100 $\mathrm{mg} / \mathrm{kgBB} /$ hari dapat mencegah penurunan kadar testosteron dalam serum tikus putih yang diberi pakan tinggi kolesterol. Hasil penelitian ini sesuai dengan hasil yang 
dilaporkan oleh Yamamoto et al. pada kelinci yang diberi pakan tinggi kolesterol terjadi penurunan kadar hormon testosteron dalam serum dan jaringan testis secara bermakna. ${ }^{(8)}$

Terjadinya penurunan kadar hormon testosteron serum darah tikus putih pada kelompok perlakuan pemberian pakan tinggi kolesterol (KP) penelitian ini kemungkinan disebabkan karena pakan tinggi kolesterol dapat meningkatkan produksi senyawa oksigen reaktif ROS (reactive oxygen species) dalam tubuh. $(9,26)$ Peningkatan konsentrasi senyawa oksigen reaktif ini bila tidak diimbangi oleh aktivitas antioksidan dalam tubuh menyebabkan terjadinya stres oksidatif yang dapat meningkatkan peroksidasi asam lemak tak jenuh pada membran sel, gangguan fungsi jalur hipofise-pituitarigonad disertai terjadinya penurunan sekresi hormon Leutinizing dari hipofisa anterior, ${ }^{(10)}$ gangguan perkembangan dan fungsi sel leydig yang akhirnya akan menyebabkan produksi hormon testosteron menurun. ${ }^{(8,10,27) H i p e r k o l e s t e r o l e m i a ~ j u g a ~}$ dapat menyebabkan penurunanan aktivitas enzim 17-beta hydroxysteroid dehydrogenase dan enzim antioksidan Superokside dismutase (SOD), Catalase (CAT), dan, glutatione peroxidase (GPx), ${ }^{(28,29)}$ peningkatan jumlah degenerasi sel Leydig, pengurangan diameter inti Leydig sel,(30)kerusakan fungsi sel-sel Leydig.(10,27) Rusaknya sel-sel Leydig mengakibatkan proses sintesis hormon testosteron serum mengalami penurunan.(25)

Penelitian ini menunjukkan bahwa pemberian ekstrak buah tomat dengan dosis $25 \mathrm{mg} / \mathrm{kgBB} / \mathrm{hari}, 50 \mathrm{mg} / \mathrm{kgBB} /$ hari dan $100 \mathrm{mg} / \mathrm{kgBB} /$ hari pada kelompok tikus putih yang diberi pakan tinggi kolesterolmampu menghambat penurunan kadar hormon testosteron serum darah, bahkan pada kelompok D3 kadar hormon testosteron serum darah relatif sama dengan pada kelompok kontrol (KN). Hasil ini membuktikan bahwa pemberian ekstrak buah tomat berperan aktif dalam peningkatan kadar testosteron serum tikus putih yang diberi pakan tinggi kolesterol. Peningkatan kadar hormon testosteron serum ini kemungkinan disebabkan efek positif dari bahan aktif yang terkandung dalam ekstrak buah tomat seperti likopen, vitamin $\mathrm{E}$, vitamin $\mathrm{C}$ dan flovanol yang bersifat sebagai antioksidan yang mampu melindungi sel Leydig testis dari kerusakan akibat peningkatan senyawa oksigen reaktif. Adanya kandungan zat-zat antioksidan pada ekstrak buah tomat akan meredam aktivitas senyawa oksigen reaktif, sehingga akan menghambat terjadinya peroksidasi lipid dan kerusakan pada sel-sel interstitial testis terutama sel-sel Leydig, sehingga produksi hormon testosteron terjaga baik. Sebagaimana dilaporkan oleh Mohammed et al. bahwa pemberian jus campuran tomat dan wortel pada tikus yang menderita hiperlipidemia selama 14 hari dapat memperbaiki sel-sel Leydig disertai peningkatan kadar hormon testosteron dalam plasma darah secara nyata.(31)

Likopen atau yang sering disebut sebagai B-karoten adalah suatu karotenoid pigmen merah terang, yang tinggi dalam buah tomatserta bersifat sebagai antioksidan dan mampu melindungi sel dari peroksidasi lipid. Kemampuan likopen dalam meredam oksigen tunggal dua kali lebih baik dari pada beta karoten dan sepuluh kali lebih baik daripada vitamin E (alfatokoferol).Sebagai antioksidan kuat, likopen melindungi DNA dari stress oksidatif dengan menonaktifkan hidrogen peroksidase dan nitrogen dioksidase serta melindungi limphosit dati nitrit dioksidase (NO) yang merusak membran dan terjadinya kematian sel.(32) Likopen sebagai antioksidan juga berperan dalam menangkal radikal bebas melalui mekanisme oksidatif yaitu memberikan elektronnya kepada elektron bebas yang terdapat pada radikal bebas sehingga akan menghasilkan senyawa 
yang lebih stabil.(28) Selain itu, penelitian yang telah dilakukan oleh Dasrul juga membuktikan bahwa pemberian ekstrak tomat dengan dosis $40-80 \mathrm{mg} / \mathrm{kg}$ selama 60 hari dapat meningkatkan kualitas spermatozoa tikus yang diberi pakan tinggi kolesterol.(32)

Selain kandungan antioksidan golongan likopen, ekstrak buah tomat juga mengandung Vitamin C, dan E yang bersifat sebagai antioksidan. Vitamin $\mathrm{C}$ atau asam askorbat merupakan antioksidan penting yang mampu melindungi sel spermatozoa dan DNA dari stress oksidatif dengan cara menetralisir senyawa ROS. Sedangkan Vitamin E yang merupakan bagian dari golongan tokoferol adalah senyawa antioksidan yang mampu menghambat terjadinya kerusakan akibat pembentukan radikal bebas pada membran sel, mencegah peroksidasi lipid dan meningkatkan aktivitas antioksidan lainnya. Banyak bukti menunjukan bahwa pemberian vitamin $\mathrm{E}$ mampu merangsang fungsi testis dalam memproduksi hormon testosteron melalui fungsinya mencegah kerusakan oksidatif pada sel Leydig. Vitamin E sebagai antioksidan akan mencegah oksidasi lemak khususnya Poly Unsaturated Fatty Acid (PUFA) untuk bereaksi dengan radikal bebas sehingga struktur dan fungsi sel membran tetap terjaga. Vitamin $\mathrm{E}$ bekerja secara chain-breaking di dalam tubuh, yang berartivitamin $\mathrm{E}$ memutuskan hubungan radikal peroksil lipid dengan cara menyumbangkan satu atom hidrogennya sehingga mampu melindungi lipid dari serangan stres oksidatif.(33) Vitamin E mampu menghentikan reaksi berantai peroksidasi lipid asam lemak tidak jenuh pada fosfolipid membran sel testis, membantu mencegah akumulasi ROS pada jaringan-jaringan yang memproduksi spermatozoa, serta melindungi fungsi spermatozoa. ${ }^{10,32)}$ Selain itu vitamin E mampu mencegah kerusakan Deoxyribonucleic Acid (DNA) yang menyebabkan mutasi, mempertahankan $L D L$ dan unsur tubuh lainnya yang kaya akan lipid dalam menangkal radikal bebas. Kemampuan vitamin E dalam mempertahankan LDL sangat mempengaruhi kadar hormon testosteron serum. LDL sendiri merupakan pembagian dari kolesterol, dimana LDL merupakan prekursor hormon testosteron serum. Apabila kadar LDL dapat dipertahankan oleh vitamin E maka prekursor bagi pembentukan hormon testosteron serum juga tersedia didalam tubuh, sehingga produksi dari hormon testosteron serum dapat meningkat. Vitamin E selain berperansebagai antioksidan, juga berperan aktif dalam memperbaiki organel sel testis, seperti reticulum endoplasma halus atau mitokondria dari kerusakan akibat peroksidasi lipid.(22,34) Perbaikan dari organel sel oleh vitamin E sangat mempengaruhi aktivitas sel Leydig, menjadi lebih maksimal kinerjanya dalam memproduksi hormon testosteron, sehingga menyebabkan terjadinya peningkatan hormon testosteron dalam serum darah. Selain itu vitamin E menyebabkan penurunan aktivitas dari aromatase testis.Aromatase testis merupakan enzim yang terlibat dalam produksi estrogen yaitu sebagai katalis bagi konversi testosteron menjadi estradiol. Penurunan dari aktivitas aromatase ini meningkatkan kadar hormon testosteron. Mekanisme untuk peningkatan total level testosteron dapat dipengaruhi via sentral yaitu mampu meningkatkan gonadotropin atau secara lokal melalui peningkatan angka darisel-sel Leydig atau sensitivitas merekaterhadap hormon luteinizing (LH). ${ }^{(34)}$

\section{Kesimpulan dan Saran}

\section{Kesimpulan \\ Berdasarkan hasil analisis dan pembahasan yang telah diuraikan oleh}


peneliti, dapat diambil beberapa kesimpulan sebagai berikut:

1. Pemberian ekstrak tomat (Lycopersicum esculentum), dapat menghambat penurunan kadar hormon testosteron pada tikus yang diberi pakan tinggi kolesterol.

2. Pemberian ekstrak tomat dosis 100 $\mathrm{mg} / \mathrm{kgBB} /$ hari lebih baik dibandingkan dengan dosis 25 $\mathrm{mg} / \mathrm{kgBB} /$ hari dan $50 \mathrm{mg} / \mathrm{kgBB} /$ hari dalam menghambat penurunan kadar hormon testosteron pada tikus yang diberi pakan tinggi kolesterol.

\section{Saran}

Berdasarkan hasil penelitian ini dapat disampaikan saran-saran sebagai berikut:

1. Perlu dilakukan penelitian lebih lanjut untuk mengetahui pengaruh pemberian ekstrak tomat terhadap perubahan histologi dan jumlah sel Leydig tikus Rattus norvegicus yang diberi pakan tinggi kolesterol.

2. Perlu dilakukan penelitian lebih lanjut untuk mengetahui pengaruh ektrak tomat terhadap tingkat peroksidasi lipid pada tikus yang diberi pakan tinggi kolesterol.

3. Perlu dilakukan penelitian lebih lanjut untuk mengetahui pengaruh ektrak tomat terhadap tingkat libido dan daya fertiltas tiks putih Rattus norvegicus yang diberi pakan tinggi kolesterol.

\section{Daftar Pustaka}

1. Tremellen K. Oxidative stress and male infertility - a clinical perspective. 2008;14(3):243-58.

2. Cahyana HN, Kaswidjanti W dan Kartikasari AA. Sistem informasi berbasis web panduan diet bagi penderita penyakit jantung. 2003. p.154-157
3. Almatsier S. Penuntun Diet. Jakarta: Gramedia Pustaka Utama; 2004. p.28-35

4. Sargowo, HD. Peran Radikal Bebas Dalam Patogenesa Arterosklerosis. Jurnal Kardiologi Indonesia. 1997. 12(3): 15

5. Diska P. Pengaruh Diet Tinggi Lemak Hewani dan Nabati Terhadap Kualitas Spermatozoa Pada Tikus Jantan strain Wistar. 1. Kedokteran Andalas. 2014. 10.

6. Pramudito, H. Perbandingan Kualitas Spermatoxzoa Pada Tikus Wistar Diabetes Melitus Dan Hiperlipidemia Artifisial.Semarang: Universitas Diponegoro: 2009.

7. Bashandy, AES.Effect of Fertility of Nigella Sativa on Male Infertility in normal and hyperlipidemic Rats. International jurnal of Pharmacology.2007: 3(1): 27-33.

8. Yamamoto $\mathrm{Y}$, Shimamoto $\mathrm{K}$, Sofikitis N and Miyagawa I. Effects of hypercholesterolaemia on Leydig and Sertoli cell secretory function and the overall sperm fertilizing capacity in the rabbit. Hum Reprod. 1999;14(6):151621.

9. Feng Y, Zhu Y, Chen X, Sha J, Fan L and Chen Q. Effects of diet-induced hypercholesterolemia on testosteroneregulated protein expression in mice liver. J Nanosci Nanotechnol. 2005;5(8):1273-6.

10. Tanaka, M, S. Nakaya, T. Kumai, M. Watanabe, N. Matsumoto and S. Kobayashi, 2001. Impaired testicular function in rats with diet induced hypercholesterolemia and or streptozotocin induced diabetes mellitus. Endocrinal. Res., 27: 109-117.

11. Šulcova, J., Štulc T,. Hill M., Hampl R., Masek, Z., Vondra K., et al.,2010. Decrease in Serum Dehydroepiandrosterone Level after Fenofibrate Treatment in Males with 
Hyperlipidemia. Physiol. Res. 54: 151157, 2005.

12. Agarwal A, Cocuzza M, Abdelrazik H and Sharma RK. Oxidative stress measurement in patients with male or female factor infertility. Handb Chemilumin Methods Oxidative Stress Assess. 2008;661(2):195-218.

13. Sumardiono $S$, Basri $M$ dan Sihombing RP. Analisis Sifat-Sifat Psiko-Kimia Buah Tomat (Lycopersicum esculentum) Jenis Tomat Apel, Guna Meningkatkan Nilai Fungsi Buah Tomat Sebagai Komoditi Pangan Lokal. Semarang: Universitas Diponegoro: 2009.

14. Campbell JK, Canene-Adams K, Lindshield BL, Boileau TW-M, Clinton SK and Erdman JW. Tomato phytochemicals and prostate cancer risk. J Nutr. 2004;134(12 Suppl):3486S 3492S.

15. Rao LG and Rao LG. Lycopene: Its role in human health and disease. Nutr Res. 1982;25-30.

16. Mokhtar, MA. , Pengaruh Pemberian Jus Tomat Terhadap Kadar Kolesterol LDL Tikus Putih.Surakarta.Universitas Sebelas Maret; 2008.

17. Isnawati, Sadikin $\mathrm{M}$, Sriwidya, Jusman dan Aulia A. Efek Pemberian Tomat Terhadap Perubahan Konsentrasi Proteason Pada Karsinogenesis Hati.Jurnal Kedokteran Indonesia.2008;58(7): 237-241.

18. Zulfah I. Pengaruh Pemberian Jus Tomat Terhadap Morfologi Spermatozoa Mencit Strain Balb/C Jantan yang Dipapar Asap Rokok.Semarang.Universitas Diponegoro:2006.

19. Selamet RN, Sugito and Dasrul. The Effect of Tomato Extract (Lycopersicon esculentum) on The Formation of Athero- Sclerosis in White Rats (Rattus norvegicus) Male. Jurnal natural Saince 2013;13(2):5-9.
20. Supranto J. Teknik Sampling Untuk Survei dan Eksperimen Jakarta: PT Rineka Cipta. 2000. p. 32-38.

21. Khairuddin, Manggau MA dan Mufidah. Uji Efek Ekstrak Etanol Sarang Semut (Hydnophtum sp) Terhadap Perubahan Bobot Badan Mencit.Majalah Farmasi dan Farmakologi.2012; 16: 1. p. 45-50.

22. Goyal A, Chopra M, Lwaleed B a., Birch B, Cooper AJ.The effects of dietary lycopene supplementation on human seminal plasma. BJU Int. 2007;99(6):1456-60.

23. Andayani R, Lisawati $Y$ dan Maimunah. Penentuan Aktivitas Antioksidan, Kadar Fenolat Total dan Likopen Pada Buah Tomat (SolanumLycopersicum L). Jurnal Sains dan Teknologi Farmasi.2008; 13: 1.

24. Budiarto E. Biostatistika Untuk Kedokteran dan Kesehatan Masyarakat Jakarta: EGC. 2001. p. 54-60.

25. Guyton C and Hall JE. Buku Ajar Fisiologi Kedokteran. Jakarta: EGC. 2007.p.882-891.

26. Ohara $Y$, Peterson $T, E$ and Harrison D,G. Hypercholesterolemia Increases Endhotelial Superoxide Anion Production. Journal Clinical Invest.1993; 91.p. 2546-2551.

27. Preedy VR, Watson RR. Tomatoes and Tomato Products.United States America.Publish by Publish Science Publisher; 2008.

28. Bashandy, AES.Effect of Fertility of Nigella Sativa on Male Infertility in normal and hyperlipidemic Rats. International jurnal of Pharmacology.2006: 2(1):104-109.

29. Bohm, $Y$ and R. Bitsch. Interstinal Absorption Of Lycopene From Different Matrices and Interactions To Other Carotenoids, the Lipid Status and Antioxsidant Capacity Of Human Plasma. Eur. J. Nutr.1999 38:118-125. 
30. Gupta NP and Kumar R. Lycopene therapy in idiopathic male infertility--a preliminary report. Int Urol Nephrol. 2002;34(3):369-72.

31. Mohammed, D.A., T.E. Hamed, and S.Y. Al-Okbi. Reduction in hypercholesterolemia and risk cardiovascular diaseas by mixturesof plant food extracts: a study on a plasma lipid profile, oxidative stress amd testosterone in rats. Grass Y Acietes. 61(4):378-389.

32. Fuhrman, B. Hypocholesterolemic effect of lycopene and $B$ - karotene is relatedisi to supression of cholesterol syntesis and augmentation of LDL receptor activity in macrophage. Biochemical and Biophysical Research Communications,1997. 233:658-62.
33. Dasrul S. Pemanfaatan Ekstrak Tomat (Lycopersicum esculentum Mill) Sebagai Antioksidan dan Antiinfertilitas Serta Potensinya Dalam Pencegahan Infertilitas Tikus Putih (Rattus norvegicus) Strain Wistar Hiperkolesterolemik. Laporan Hasil Penelitian Hibah Pasca Sarjana. Universitas Syiah Kuala, 2013.

34. Momeni, Hamid R, Mehranjan, Malek $\mathrm{S}$, Abnosi MH, Mahmoodi, et.al., Effects of vitamin $\mathrm{E}$ on sperm parameters and reproductive hormones in developing rats treated with para-nonylphenol. Iranian Journal of Reproductive Medicine 2009. 7 (3):111-116. 